\title{
THIAMPHENICOL IN THE TREATMENT OF CHANCROID. A STUDY OF 1,128 CASES
}

\author{
Walter BELDA JUNIOR(1), Luis Fernando de Goes SIQUEIRA(2) \& Luiz Jorge FAGUNDES(2)
}

\begin{abstract}
SUMMARY
Thiamphenicol, an aminic derivate of hydrocarbilsulfonil propandiol, was used for the treatment of 1,171 chancroid bearing patients. Each patient was medicated with $5.0 \mathrm{~g}$ of granulated thiamphenicol, orally, in a single dose, and was reevaluated 3, 7 and 10 days after the treatment. Ten patients $(0.89 \%)$ did not respond to the proposed treatment. 133 patients presented healed ulcers after 3 days of treatment, 976 patients healed chancres on the seventh day after the treatment, and 39 patients took 10 days to present healed chancres. The results of this study indicate that the rate of patients that were cured, the low incidence of side effects, and the practicality of administration make of thiamphenicol an excellent choice for the treatment of chancroid.
\end{abstract}

KEYWORDS: Thiamphenicol; Chancroid; Therapy

\section{INTRODUCTION}

Thiamphenicol (dextrosulfenidol) synthezised in 1951, belongs to the group of hydrocarbilsulfonil propandiol aminic derivates, obtained from methylmercapto acetofenona. According to MINGOIA ${ }^{7}$, "The only antibiotic similar to chloramphenicol that has drawn some attention and presents some superiority over the natural antibiotic is thiamphenicol, characterized by the methylsulfonic radical instead of the nitrogroup". At a sub-cellular level, thiamphenicol inhibits the protein synthesis, joining the ribosomes and thus preventing the binding of the amino acid with the peptiltransferase.

Chloramphenicol's toxic side effects are attributed to the substances of reduction caused by the nitrogroup. With thiamphenicol, instead of this group $\left(\mathrm{O}_{2} \mathrm{~N}\right)$ there is methylsulfonila $\left(\mathrm{CH}_{3} \mathrm{SO}_{2}\right)$, thus the inexistence of such risks. Anemia, found in prolonged treatments, is reversible. There is no risk of relative overdose in individuals with altered hepatic function. In vivo studies in which high doses of thiamphenicol have been given belie any role of this drug in altering the lymphocytic blastogenesis ${ }^{8}$.

Minor reversible side effects, like nausea, headache, diarrhea, gastralgia and skin prurigo or rash have been reported ${ }^{1}$. Although its action is basically bacteriostatic, thiamphenicol, in the same concentration, proved bactericide for members of species of Streptococcus, Neisseria, Klebsiella and Brucella, being active against Chlamydia, Mycoplasma and several other anaerobic organisms. It doesn't present any activity against Mycobacterium tuberculosis and Trichomonas vaginalis ${ }^{2}$.
Ulcers of mixed etiology, problems of bacterial identification on culture or slides, are possibly precluding the real understanding of the problem. Due to their growing resistance or the need of a long-term regimen, classical drugs demand continuous research not only on new but also more simplified therapeutic options, in order to prevent the patients' evasion and/or treatment interruption.

Based upon former experiments with thiamphenicol we have employed the product in a single dose of $5.0 \mathrm{~g}$, taking into account that a convenient route of administration, short treatment period and a specific antibacterial spectrum are the most important factors for a optimal treatment strategy.

Since 1984, thiamphenicol has been used in the treatment of chancroid, sporadically at the beginning, in the form of capsules and with a ten day long treatment ${ }^{3,6}$, and later, in a granulated form in a single dose $\mathrm{e}^{4,5}$.

\section{PATIENTS AND METHODS}

The study group included male patients bearing chancroid, attended at the Sexually Transmitted Diseases Service, Dermatology Division, Hospital das Clínicas, Faculty of Medicine, São Paulo University and Faculty of Public Health from University of São Paulo, during the period comprised between 1984 and 1999. The diagnosis was confirmed by the clinical characterization of genital chancres, necrotic and painful, and laboratorially, with negative research for Treponema pallidum in darkfield microscopy; identification through direct bacterioscopy with Gram 
staining, negative gram bacillus forming palisades or simple chains and/ or in a typical disposition in the polymorphonuclear cytoplasm, on material obtained from chancre pus.

As soon as the clinical laboratory diagnosis was established, the patients received $5.0 \mathrm{~g}$ of granulated thiamphenicol, dissolved in $50 \mathrm{ml}$ of water, in a single dose, by mouth. The patients were evaluated clinically and laboratorially 3, 7 and 10 days after medication.

A total of 1,171 patients, all of them male, whose age distribution is in Table 1 , were evaluated.

Table 1

Age distribution of patients

\begin{tabular}{ccc}
\hline AGE & No. PATIENTS & $\%$ \\
\hline $15-20$ & 275 & 23.48 \\
$21-25$ & 550 & 46.96 \\
$26-30$ & 220 & 18.78 \\
$31-35$ & 36 & 03.07 \\
$36-40$ & 55 & 04.69 \\
$41-45$ & 18 & 01.53 \\
$46-50$ & 17 & 01.45 \\
\hline TOTAL & 1,171 & 100 \\
\hline
\end{tabular}

\section{RESULTS}

At the first clinical laboratory reevaluation, which took place 3 days after the treatment, 133 patients $(11.35 \%)$ presented totally healed lesions; 10 patients $(0.85 \%)$ didn't return for the first check up. The rest presented ulcerated lesions and, of these, $7.17 \%$ (84 patients) still presented purulent secretion from the lesions, in a lesser quantity, although positive for Haemophilus ducreyi.

On the second reevaluation, which took place 7 days after application, 1,076 patients $(91.88 \%)$ presented completely healed chancres; 33 patients didn't show up to this second check up and 10 patients $(0.87 \%)$ still presented open chancres and positive Haemophilus ducreyi research on a microscopic slide.

At the final evaluation, which took place 10 days after the treatment, 1,115 patients $(98.84 \%)$ presented healed lesions, 3 patients still presented open lesions though non-reactive for Haemophilus ducreyi, and 10 patients persisted with ulcerated lesions and positive research on the microscopic slide for Haemophilus ducreyi.

After 3 weeks of treatment, the 3 patients who still presented open lesions at the 10th day of the reevaluation were completely healed.

Few patients showed side effects, which included epigastralgia, headache, nausea and skin rash, all of them light in intensity and of short duration.

\section{DISCUSSION}

The results at the therapeutic evaluation were related to the confirmed disappearance of Haemophilus ducreyi, the disappearance of clinic symptoms (pain) and healing of the ulcers. At the evaluation carried out on the third day of application, 10 patients $(0.85 \%)$ did not show up; 133 patients $(11.35 \%)$ had healed lesions, with no possibility of a bacterioscopic exam, 1,028 patients presented open lesions, ten of which still presented a positive Haemophilus ducreyi research on the microscopic slide. At the second evaluation, carried out after seven days of treatment, 33 more patients failed to show up. Hence, there was a loss of 43 patients. Of the 1,128 patients who were evaluated on the seventh day, 1,076 (95.39\%) presented healed lesions and $10(0.89 \%)$ remained with open lesions and with positive research for Haemophilus ducreyi.

On the third and last evaluation carried out 10 days after the treatment, 1,115 patients $(98.84 \%)$ presented healed lesions; 3 patients retained open lesions although non-reactive, and 10 patients $(0.89 \%)$ retained open lesions and positive reaction on the slide. These ten patients were then considered as a therapeutic failure and alternative medication was then introduced.

After 3 weeks, the 3 patients who still presented open lesions at the third evaluation with negative direct research, were reevaluated, and found that their ulcers had already healed. Of the 1,128 patients who completed the study, 133 presented lesions healed in 3 days; 976 patients presented a healing between 3 and 7 days after medication and, 39 patients presented a healing between 7 and 10 days after the treatment. Three patients showed a healing time between 10 days and 3 weeks (Table 2 ).

Table 2

Healing time after therapy with thiamphenicol

\begin{tabular}{cc}
\hline DAYS & No. PATIENTS \\
\hline $0-3$ & 133 \\
$3-7$ & 976 \\
$7-10$ & 39 \\
$10-21$ & 03 \\
\hline
\end{tabular}

We thus obtained a clinical laboratoty cure in $99.11 \%$ of the patients, with only 10 patients $(8.9 \%)$ not responding to the proposed medication, making it necessary to use an alternative medication. Few patients presented side effects, and these were of light intensity and short duration.

The high cure rates, the absence of serious side effects, the low cost and the practical administration make of thiamphenicol an excellent choice for the treatment of chancroid.

\section{RESUMO}

\section{Tianfenicol no tratamento do cancroide. Estudo de 1.128 casos}

O tiamfenicol, derivado amínico do hidrocarbilsulfonil propandiol, foi utilizado para o tratamento de 1.171 pacientes portadores de cancróide. Cada paciente foi medicado com 5,0 g de tianfenicol granulado, via oral e em dose única, sendo reavaliados após 3, 7 e 10 dias do tratamento. Dez pacientes $(0,89 \%)$ não responderam à terapêutica proposta; 133 pacientes apresentaram úlceras cicatrizadas após 3 dias do tratamento; 976 pacientes apresentaram lesões cicatrizadas no sétimo dia após o tratamento e, 39 pacientes levaram 10 dias para apresentarem lesões 
cicatrizadas. Os resultados deste estudo indicam que o índice de cura, a baixa incidência de efeitos colaterais, e a praticidade de administração fazem hoje do tianfenicol uma excelente escolha no tratamento do cancróide.

\section{REFERENCES}

1. BELDA, W. - O tratamento da uretrite gonocócica aguda masculina pelo tianfenicol: uma revisão. Rev. bras. Clín. Terap., 7: 375-379, 1978.

2. BELDA, W.; SANTOS JR., M.F.Q. \& BELDA JR., W. - Thiamphenicol in the treatment of male gonococal urethritis. Sex. transm. Dis., 11: 418-419, 1984.

3. BELDA, W.; SANTOS JR., M.F.Q.; BELDA JR., W. et al. - Novos rumos no tratamento do cancro mole. Experimentação clínica com thiamphenicol. An. bras. Derm., 59: 147-149, 1984.
4. BELDA, W.; SANTOS JR., M.F.Q.; SIQUEIRA, L.F.G. et al. - Emprego do tianfenicol granulado, em dose única de $5 \mathrm{~g}$ no tratamento do cancro mole. An. bras. Derm., 59: 209-212, 1984.

5. BELDA JR.,W.; SANTI, C.G.\& MIRANDEZ, A.A.- Tratamento do cancróide com tianfenicol. Rev. bras. Med., 42: 204-205, 1985.

6. LATIF, A.S.; CROCCHIOLO, P.R. \& LENCROW, R. - Thiamphenicol in the treatment of chancroid in men. Sex. transm. Dis., 11: 454-455, 1984.

7. MINGOIA, Q. - Tianfenicol e cloranfenicol: diferenciação química e farmacológica. Rev. bras. Clín. Terap., 6: 495-500, 1977.

8. PASTERNAK, J. - Cloranfenicol - tianfenicol. Aspectos conhecidos e desconhecidos das interações fármaco-hospedeiro. Rev. bras. Clín. Terap., 5: 259-262, 1976.

Received: 25 November 1999

Accepted: 17 April 2000 


\section{BOOK REVIEW*} BALOWS, Albert \& DUERDEN, Brian I - Systematic Bacteriology. London, Arnold, 1998. 1501p. ilus. (TOPLEY \& WILSON'S
MICROBIOLOGY AND MICROBIAL INFECTIONS. Ninth Edition. v.2). ISBN 0340663170 (Volume 2). ISBN 0340 614706 (Set).

The period since publication of the first edition in 1929 has seen various modifications in the form and content of Topley and Wilson, perhaps the most important of which was the change with the $7^{\text {th }}$ edition to a multi-author work in four volumes. This, the $9^{\text {th }}$ edition marks spectacular departures from past policy.

The $9^{\text {th }}$ edition is designed to make the volumes more self-contained and descriptions of the immune response as it relates respectively to viruses, bacteria and the eukaryotic parasites are provided in the appropriate volumes.

The standard of the illustrations, many of which are now in colour, is considerably higher than in previous editions. The quality of the references has been greatly improved by providing the titles of papers and both first and last pages.

Change in a work of this nature is inevitable and this edition of the volume on SYSTEMATIC BACTERIOLOGY is a dramatic departure from its predecessors in many ways. Each chapter has been rewritten in its entirety to present new information on the biotechnical and molecular aspects of bacteria while retaining the fundamentals of bacteriology. Students of medical microbiology and infectious diseases should benefit from this fresh approach in presenting the basic facts of bacteriology and in describing the various genera of bacteria responsible for infectious diseases.

This volume consists of 64 chapters. These reflect a combination of the chapters dealing with general bacteriology and with specific genera of pathogens in volumes 1 and 2 of the $8^{\text {th }}$ edition respectively.
The first 19 chapters cover fundamentals of bacteriology with a strong leaning to those topics that are of interest to students, research workers and teachers of microbiology. Following an historical introduction by M.T. Parker, the next 6 chapters deal with how bacteria are built, grow and become part of the biosphere, and comprise topics such as structure, morphology, metabolism and diversity. The next 4 chapters address the ways in which bacteria compete in their environment: viz., bacteriocins and bacteriophages, the effects of antibiotics, bacterial genetics, human microflora and bacterial diversity. These are followed by chapters covering the role of bacteria in our environment: soil, air, water, dairy products and foodstuffs. An additional segment of fundamentals is contained in 4 chapters dealing with classification and taxonomy, isolation and identification, and immuno-serology. The last 45 chapters contain comprehensive descriptions and discussions of bacterial genera or groups of bacterial pathogens with coverage extending to new, emerging or reemerging pathogens as well as current information on established pathogens.

From the Editor-in-chief Preface and Volume Editors' Preface

\author{
Arnold, a member of the Hodder Headline Group \\ 338 Euston Road, \\ London, NW1 3BH - England \\ Co-published in the United States of America by: \\ Oxford University Press, Inc. \\ 198 Madison Avenue, \\ New York, NY 10016 - USA
}

